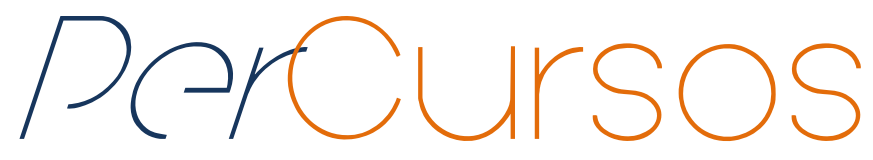

\title{
Moda masculina em Nossa Senhora do Desterro: século XIX
}

\section{Resumo}

Este artigo se propõe a analisar as práticas de masculinidades na Ilha de Santa Catarina na segunda metade do século XIX. Nada passava despercebido pelos ávidos de cosmopolitismo. E entre as várias intervenções diante do comportamento masculino analisaremos o vestuário e sua indumentária como distinção da nova sociedade que nascia nos meandros do mundo burguês. A sociedade cidadina do segundo império requeria e solicitava cuidados na maneira de "ser" e de "estar" inserido na incipiente burguesia desterrense. Nesta perspectiva o vestuário masculino tornou-se alvo de críticas dos transformadores da inebriante sociedade desterrense do século XIX. O vestuário e a indumentária masculina em Nossa Senhora do Desterro difundiam neste período a imagem do homem moderno e com lugar privilegiado na nova cartografia e tipologias inoculadas na tessitura da sociedade do Desterro.

Palavras-chave: Masculinidade. Sociabilidade. Moda. Elegância e afetividade.

\author{
Antônio Emilio Morga \\ Professor do Departamento de \\ História e do Programa de Pós- \\ Graduação em História - UFAM \\ aemorga@ibest.com.br
}

\section{Para citar este artigo:}

MORGA, Antonio Emilio. Moda masculina em Nossa Senhora do Desterro: século XIX. Revista

PerCursos. Florianópolis, v. 14, n.27. jul./dez. 2013. p. 200 - 220.

\section{DOI: $10.5965 / 1984724614272013200$}

http: //dx.doi.org/10.5965/1984724614272013200 


\title{
Masculine Fashion: Nossa Senhora do Desterro city on the nineteenth century
}

\begin{abstract}
This article targets to analyze the masculinities' practices on the Island of Santa Catarina in the second half of the nineteenth century. Nothing went unnoticed by those who were avid of cosmopolitanism. And among the various interventions on male behavior, we will analyze their clothing and their outfits as distinction of the new society that was being born in the intricacies of the bourgeois world. The citydweller society of the Second Empire required and requested close attention in the way of actually "being" and "acting now" inserted in the incipient, native bourgeoisie. From this point of view, men's clothing had become the target of criticism from the transformers of the heady, native society of the nineteenth century. The men's clothing and outfits in the city of Nossa Senhora do Desterro diffused in this period, the image of the modern man with a privileged place in the new cartography and typologies inoculated in the rhythm of the Desterro society.
\end{abstract}

Keywords: Masculinity. Sociability. Fashion.

Elegance and affectivity. 


\section{Introdução}

Poder-se-ia dizer que nos primórdios da colonização da Ilha de Santa Catarina "As ceroulas eram de uso geral”. Toda população masculina praticamente fazia uso diário dessa vestimenta, seja na labuta ou na intimidade do aconchego familiar. Aos mais pobres ceroulas confeccionadas de algodão, de pano americano, que alvejava com o tempo e com as lavações, ou de riscadinho grosseiro, enquanto os mais abastados diferenciavamse com estilo. Do ventre desciam, pernas abaixo, atacando-se no alto por três ou quatro botões de osso, este modelo determinava a proeminência abdominal, reveladora da fortuna do portador, e como acabamento prendendo-se abaixo das pantorrilhas, junto aos tornozelos, por cadarços que faziam todos os esforços para se exibir. "Se ceroulas de quatro botões de osso indicava a posição social dos homens, o chale indicava a classificação econômica das mulheres que os usavam, pois havia-os debruados com galões de ouro, prata, sêda, etc....". (CABRAL , p. 325-336)

Diante de uma natureza exuberante e noites de interlúnios, homens de ceroulas “de algodão, de linho, de pano americano ou de riscadinho grosseiro" desfilam pelas intensas vidas que pulsavam nas latejantes e desejosas intimidades de Nossa Senhora do Desterro. Na candura familiar, logo após jornada intensa de intensas horas de trabalho, homens de negócios, biscateiros, padres, juizes, militares, políticos, desocupados e funcionários públicos enquanto esperavam o jantar entregavam-se à prática da ociosidade.

Mal chegava em casa, o negociante, o funcionário categorizado, o vereador, o deputado, largavam tudo. Nos tempos mais recuados, metiam-se nos tamancos e ficavam à vontade, de ceroulas e camiseta de meias mangas, ou mesmo com a camisa, sem os complementos dos peitilhos, colarinhos e punhos. (CABRAL, p. 326)

E quando a noite chegava e da varanda não se podia distinguir quem chegava ao portão, tamanha a escuridão que invadia as ruas de Nossa Senhora do Desterro, e o olhar timidamente alcançava um ponto luminoso de algum candeeiro a reluzir a metros de 
distância, “[...], damas e cavalheiros metiam-se em amplos camisolões, enfeitados de "gregas" vermelhas na gola e nos punhos, nada por baixo, o corpo liberto de tôdas as peias e de todos os constrangimentos". (CABRAL , p. 338)

Nas buliçosas noites desterrenses corpos seminus se deitavam lúdicos e se deleitavam pelas libertinas e longas noites de inverno molhadas e bolinadas pelo vento sul. Madrugadas iluminadas por estrelas e luas de verão povoavam a aprazível e romântica Ilha de Santa Catarina. Assim, distraidamente, como não quisessem nada, sonhos, desejos e mãos cobiçosas iam escorrendo sob o lençol macio e branco que se misturava ao cheiro do corpo liberto de todas as peias e de todos os constrangimentos.

Vários viajantes estrangeiros que visitaram a Ilha de Santa Catarina nos séculos XVIII e XIX foram enfáticos ao afirmarem que a população vivia na penúria e que muitas vezes não possuíam o mínimo necessário para viver. E entre as carências materiais a que mais intensamente aflorava era a que se referia ao vestuário: "a Vila do Desterro sentiu profundamente a carência de roupas de vestir, tão acentuada que os moradores davam preferência", (Cabral, 1979, p. 317) nas relações comerciais que estabeleciam com os viajantes estrangeiros, na troca de seus produtos - madeira, milho, peixe, galinha, limão, batata, porco, madeira, carne de caça, frutas e farinha - por roupas, fazendas e calçados. Com isto tentavam amenizar, numa terra pouco provida, os infortúnios dos primórdios da colonização.

Dezembro de 1803. Final de tarde... Céu azul... Mar de verão... Ao longe o anoitecer anuncia-se diante do regozijo das árvores em movimentos languidamente suaves e sinuosos. O navio que traz a bordo o médico G. H. von Langsdorff lentamente se aproxima do porto da Vila do Desterro. Langsdorff com o coração a pulsar febricitante e extasiado pelo "panorama da paisagem à sua frente, coberta por uma roupagem de um verde vivo, semeada de flores multicolores" finalmente desembarca na llha de Santa Catarina (LANGSDOFF, 1984, p.163). Esta descoberta desperta no coevo viajante alemão o mais confortável bem-estar. E, diante dessa generosidade da natureza e: 
Excitado por tão belas imagens de minha fantasia, mal podia aguardar o retorno do sol para visitar a região paradisíaca. Confesso que minhas idéias eram exageradas e tensas, mas apesar disto, quanto mais eu me aproximava da terra, a realidade excedia minha expectativa. (Ibidem, $\mathrm{p}$. 162)

Na Ilha, o médico Langsdorff observou e registrou no seu relato de viagem os usos e costumes da população, bem como a riqueza da flora e da fauna. Seu olhar também perscrutou os modos de vida da Vila de Nossa Senhora do Desterro nos primórdios do século XIX, período de ajustamento à nova ordem econômica, legislativa, policial, jurídica, social e cultural. Processo que vinha ocorrendo desde 1726 quando a llha de Santa Catarina foi elevada à categoria de Vila.

Após relatar sobre as práticas de sociabilidade da comunidade o viajante no item referente à moda assevera que "O vestuário de ambos os sexos é europeu; considerando que todo ele é constituído de fazendas finas e leves, portanto, usa-se com muita frequência a musselina, o linho, o manquim e fina seda". (CABRAL , p. 163)

O oficial norte-americano David Porter que chegou à Ilha na véspera das comemorações natalinas de 1812, em seu relato de viagem, além de descrever vários aspectos do viver da população, tece comentário sobre o vestuário: “A gente da aldeia é bem vestida, agradável e jovial no aspecto". (PORTER, 1984, p. 219)

No outono de 1822, num entardecer de vento sul e chuva, o navegador francês Louis Isidore Duperry desembarca no porto do Desterro. Logo pela manhã, ao fazer um pequeno passeio pelos arredores do largo do palácio e ao visitar o pequeno comércio, descreve o vestuário feminino:

Embora ponham um certo esmero em seus adornos, elas usam vestimentas simples de uma limpeza notável. Um vestido leve de chita que desenha uma estrutura bem apanhada, algumas flores colocadas com arte sobre a bela cabeleira, Ihes dão um ar provocante. Elas possuem aquela coqueteria tão comum ao seu sexo, [...], pois que frequentemente fazem amizade com os marinheiros que aportam em suas costas. (DUPERREY, 1984, p. 258) 
Auguste de Sant-Hilaire (1820), em sua viagem pela Província de Santa Catarina observou os vários aspectos da formação social, cultural, política e econômica da província e, ao conviver com as práticas de afetividade e de sociabilidade da população da Capital da Província, registra que

Os homens mais abastados se vestem geralmente bem. Os que vivem no campo não se trajam com tanto apuro quanto suas mulheres; não obstante, apresentam-se mais bem vestidos do que os habitantes de Guaratuba e São Francisco. Geralmente usam sapatos e um chapéu de feltro, calças de algodão e uma jaqueta, sempre limpa, de chita ou de pano grosso. (SAINT HILAIRE, 1978, p. 174)

O abade beneditino Antoine Joseph Pernetty, que esteve na Ilha em 1763, ao participar de um jantar na casa do Governador observa que o vestuário da população masculina, mais abastada, era de bom gosto e qualificava socialmente o cavalheiro.

Os que ganham mais, utilizam um chapéu de forma muito alta, com abas de quase dez polegadas abaixadas. Estes estão cobertos e usam um paletó, acrescido de um casaco amplo que vai até aos pés, levantando às vezes a ponta de baixo para o ombro do lado oposto. Ao invés do chapéu, alguns usam um capuz do mesmo tecido do casaco, onde está preso e serve para cobrir a cabeça, costume este que impede mesmo a seus amigos de serem reconhecidos. (PERNETTY, 1984, p. 83)

Também, não passou despercebido para o coevo viajante o traje da população que não frequentava os salões iluminados do Governo, dos saraus, dos concertos, da política, do comércio e do quartel. "Andam descalços, cabeça descoberta e muito mal penteados; suas roupas consistem em uma camisa, uma calça e às vezes um casaco que jogam nas costas, à maneira dos espanhóis". (Ibidem, p.83)

Esta situação de penúria social, econômica, política e cultural em que vivia a Ilha de Santa Catarina teve uma relativa melhora com a vinda de casais açorianos no transcurso do século XVIII. De 1748 a 1756 chegaram em Nossa Senhora do Desterro 3.525 colonos provenientes das Ilhas dos Açores e da Madeira. Segundo o historiador desterrense, 
Oswaldo Rodrigues Cabral, ao finalizar o século XVIII, as lojas de fazenda da Vila do Desterro eram 18, espalhadas pelo seu centro urbano onde se encontravam os mais variados produtos. Entre eles,

[...], setins de seda e de lã, veludos, chitas, chales, novelos de fio de algodão, linhos brancos e de côres, lenços de linho e de algodão (brancos), lenços de tabaco (aquêles vermelhos, [...], de meio metro quadrado, para desentupir narinas atulhadas de rapé...), meias de sêda, sarjas e pomadas de cheiro (devia ser brilhantina, para a garforinha da rapaziada de ambos os sexos [...]. (CABRAL, p. 318)

O tempo passou, e a incipiente burguesia desterrense inoculava no cotidiano a pedagogia da sociabilidade e das sensibilidades. Práticas de afetividade que difundiam o processo civilizador que, ao introduzir gestos e falas sob e sobre a população, disseminava paralelamente discursos referentes ao viver. Agora a cidade de Nossa Senhora do Desterro (1823), em sintonia com a modernidade, tratava de se adequar e se inserir no moderno, o que a impelia a marchar num passo firme no caminho da virtude e da prosperidade.

Com o correr dos anos, já se tornara possível encontrar, no Destêrro, não só fazendas para as classes mais pobres poderem confeccionar o seu próprio vestuário como, também, às que foram um pouco mais abonadas - famílias de oficiais, de funcionários, dos primeiros comerciantes e açambarcadores, que já iam forrando o seu pé de meia - permitir que se apresentassem em melhores condições. (CABRAL, p. 318)

Então diante da tímida prosperidade em que fervilhava a Capital da Província de Santa Catarina, publica-se através das páginas do jornal O Despertador que na loja do Barbeiro situada na rua da Constituição n. 1 encontravam-se à venda Paletós de Brim.

Na rua da Constituição n. 1 (loja do Barbeiro) a um completo sortimento de paletós de brim, bem feitos e boa fazenda, para homens e meninos, que se vendem pelo diminutivo preço de $2 \$ 500$ a $3 \$ 500$; a pessoa que comprar de 20 para cima, faz-se abatimento no preço. (Jornal 0 Despertador, 29-06-1869) 
Neste período a vila e a cidade de Nossa Senhora do Desterro passava por um processo de re-ordenamento urbano e privado. Através dos jornais população e Governo tratavam de criticar usos e costumes antes propícios para arte do bem viver, mas agora inadequados e repletos de vícios que corroem a vida familiar moderna.

Poder-se-ia dizer que apesar das contradições dessa sociedade à beira mar, entre continuidade e descontinuidade se construía a sociedade desterrense do século XIX. Acompanhando as transformações urbanas que se processavam na llha, os discursos dos novos hábitos e atitudes rapidamente propagavam a difusão da pedagogia da cordialidade, "em que são relatados a emoção despertada pelas modas e pelas extravagâncias da aparência, o sentimento do tempo que passa através das diferentes modas do vestir". (LIPOVETSKY, 1989, p. 31)

Tratava-se de criar uma sociedade em sintonia com a modernidade, e o vestuário, por sua vez, tornava-se elemento cuja simbologia remetia à arte das representações das sensibilidades e das sociabilidades, agora colocada na esfera do domínio público. "Nessas condições, poderá organizar-se um sistema de frivolidades em movimento perpétuo, uma lógica do excesso, jogos de inovações e de reações sem fim”. (Ibidem, p. 29)

Com isto, continuadamente, a púbere sociedade desterrense do século XIX colocase na posição de fiadora das clivagens das condutas operacionalizadas na vila e na Capital da Província de Santa Catarina. Educar, envolver, elaborar e administrar intimidades públicas e privadas tornava-se indispensável diante dos antiquados códigos de comportamento. E entre os dispositivos de controle das atitudes, o vestuário traz consigo signos que marcam a tênue fronteira das conveniências e das simulações sociais.

Para que o reino das frivolidades possa aparecer, será preciso que sejam reconhecidos não apenas o poder dos homens para modificar a organização de seu mundo, mas também, mais tardiamente, a autonomia parcial dos agentes sociais em estética das aparências. ( Ibidem, p. 28) 
O vestuário provoca frequentes efusões que trazem à superfície a desmesura da tímida prosperidade que Nossa Senhora do Desterro experimentava. A necessidade de estar bem trajado diante não somente das conveniências sociais, mas, sobretudo, diante das formalidades de um mundo público, requeriam certos cuidados. É "em função do olhar sobre si mesmo, e dos olhares dos outros e do mundo, que se estrutura um exame permanente, obcecante". (CORBIN, 1991, p. 457)

Na simbiose entre o privado e público, estratégias sutis de refreamento das atitudes masculinas, deságuam referências que sugerem um completo déshabiller. Suportar as emoções sem incorrer em pieguice buscando o "equilíbrio entre os gestos necessários e os sentimentos socialmente aceitáveis" para (Vicent-Buffault, 1988, p. 2245) constituía um dos dispositivos a ser absorvido e observado através da assimilação das tipologias colocadas à disposição daqueles que referendavam os novos usos e costumes. Dessa forma, os sujeitos e seus entornos apoderavam-se de mecanismos capazes de enfrentar um espetáculo incansável de entrecruzamentos de significados, onde o bailar nômade das condolências indicam a atitude a seguir.

No outono de 1852, em sua coluna de variedades, o periódico "O Argos" transcreve do Jornal "Tribuna Católica" editorial associando o vestuário masculino e feminino à moral e às conveniências sociais.

O traje de qualquer pessoa de educação apurada deve sempre guardar a phisionomia do seu destino, queremos dizer, que o vestido para ser honesto, distinto e apropriado, precisa não offender de modo algum as conveniencias sociaes. Assim também deve se comportar o traje masculino que deve preservar a distinção de um verdadeiro cavalheiro. (Jornal O Argos, 22-05-1852)

O mesmo jornal, seis meses depois, publica Pensamentos Morais, onde o foco das prescrições se dimensionava sobre as condutas de sociabilidade e afetividade masculina.

Os homens circunspectos e prudentes afligem-se com as loucuras dos insensatos. Mas, apesar de serem delas vitimas, sabem abster-se de corresponde-lhes no mesmo tom. 
Os doutos tem o costume de dar sua qualificação privativa aos homens sensatos, que odeiam, sem que por isso lucrem mais do que ser reconhecidos.

$[\ldots]$.

O ridículo é arma do ignorante, a do sábio o silêncio.

A um silencioso recato, que melhor censura as loucuras do imprudente, do que mil discursos.

Feliz o homem, cujos males, que inocente sofre, podem dar-lhes motivo de ser útil pela expansão de sua alma magra em recente avisos de experiência. (Jornal Correio Catharinense, 22-12-1852)

Na medida em que a Vila de Nossa Senhora do Desterro, seguindo o modelo português, ia se constituindo como sociedade jurídica, legislativa, policial e responsável pela execução de obras públicas, uma tímida prosperidade começava a se desenhar na cartografia social.

A sociedade fora, aos poucos, tomando um certo requinte, a população aumentando, as fortunas se consolidando, os funcionários multiplicandose - e isto trazia dinheiro para o Dêsterro, que agora já o apreciava devidamente, já não vivia de trocas e escambos... Muita gente de fora trouxe novos hábitos, novas modas, novos requintes, que foram sendo adotados pelos que não saíam da Ilha, pelos que não viajavam e que só assim, por imitação do que viam, poderiam aceitar novas maneiras de ser. (CABRAL, 1979, p. 319)

Nesta ambiguidade de olhares, Desterro no decorrer do século XVIII e XIX foi se constituindo como centro urbano com características oriundas dos anseios da incipiente burguesia que, ao difundir a tipologia desejada de sociedade, traçava a cartografia da cidade higienizada, próspera e cosmopolita.

A alta sociedade foi tomada pela febre das novidades, inflamou-se por todos os últimos achados, limitou alternadamente as modas em vigor, [...], houve um verdadeiro esnobismo por tudo o que é diferente e estrangeiro. Com a moda, aparece uma primeira manifestação de uma relação social que encarna um novo tempo legítimo e uma nova paixão própria ao Ocidente, a do “moderno". (LIPOVETSKY, 1989, p. 33) 
Nas crônicas dos periódicos locais, notas, publicações a pedido, anúncios e nos relatos dos viajantes estrangeiros que visitaram a llha raro não se encontram elogios à grã-finagem da população do Desterro. Receptiva para com as novidades além-mar, e ávida pela modernidade que faceiramente percorria a Europa e balançava o conservadorismo europeu do século XIX, Nossa Senhora do Desterro através dos agentes transformadores tratava de assimilar e adequar-se aos novos ditames do bem viver.

A novidade tornou-se fonte de valor mundano, marca de excelência social; é preciso seguir "o que se fez" de novo e adotar as últimas mudanças do momento: o presente se impôs como eixo temporal que rege uma face superficial mas prestigiosa da vida das elites. (LIPOVETSKY, 1989, p. 33)

E para os amantes da arte de charutear publica-se nas páginas do Jornal "O Despertador" que na Rua do Príncipe se encontra à disposição dos distintos cavalheiros charutos de diversas procedências, bem como variado estoque de chapéus.

Acha-se um grande sortimento de charutos de todas as qualidades garantidas e de preço moderados na rua do Príncipe n. 35. Juntamente na mesma casa se achará um grande sortimento de chapéos, [...], bem como tudo mais pertencentes a ambos os sexos e por preços muitos comodos, ultimamente chegados do Rio de Janeiro. (Jornal $O$ Despertador, 22-01-1870)

Assim como havia os amantes de charutos, havia também aqueles que preferiam o rapé. "Gente do povo, com o primeiro entulhava as narinas, para espirrar - fazia bem! ou para evitar o mau cheiro das ruas e outros lugares, o que não fazia bem, mas muito bem...”. (CABRAL, 1979, p. 330)

Enquanto isso, nos elegantes salões desterrenses, os jovens homens desfilavam pelos saraus "nas suas sobrecasacas, de luvas e calças brancas e escarpins de verniz". Os homens mais velhos tinham preferência pela sala de reunião dos cavalheiros, onde saboreavam "o seu charuto em vez de bailar com a mulher, reumática ou pesadona". (Ibidem, p. 26-8-9) 
É neste momento da entrega despudorada de qualquer olhar que a masculinidade vai tecendo ponto por ponto a intricada combinação das relações sociais que "Mostra bem o caminho percorrido pelo pudor". Fugir da mulher "reumática ou pesadona" e de suas pudicícias cotidianas tinha suas artimanhas. "A cortesia nascente impõe uma nova arte de viver, mais requinte, em atenção às mulheres". (BOLOGNE, 1990, p. 57). E entre uma baforada e outra do aprazível charuto a percepção do indivíduo e do mundo que o circunscreve encontram-se na solidão "momentânea, fugida e efêmera a que a festa dava origem". (SOUZA, 1987, p. 160)

Símbolo da prosperidade, o cuidado de si requeria certas acuidades diante de si e diante do outro. Os signos e suas interpretações plurais diante dos acontecimentos levam o homem ao encontro de um receituário sobre o comedimento das sensibilidades que valorizavam a individualização e a intimidade. O homem circunspeto torna-se um bem a ser conquistado pelo exercício extenuante na busca de uma individualidade e identidade. “Os homens "bem", que dantes cortavam os cabelos e faziam a barba em casa pela mão dos escravos, passaram às barbearias. Não só para cuidar dos cabelos como da barba, dos bigodes, aparando-os, tingindo-os, perfumando-os". (CABRAL, 1979, p.346)

Narra-se que a púbere juventude da Ilha de Santa Catarina,

Contentava-se com um bigodinho, bigodinho muito cuidado, frisado, a ferro quente, de pontinhas arrebitadas e retorcidas, bem ensebado com alguma pomada cheirosa - e não como hoje, dêsses bigodões tipo vassoura de pêlo. Com a idade, os bigodes cresciam, de acôrdo com a posição - e na idade provecta, já atingiam às proporções de bigodes tomadores de sopa, e nela se molhavam, dentro das colheres. (CABRAL, 1979, p. 346)

Instrumento da ascensão social, o bigode no século XIX se constituía como artifício da corrente ininterrupta do doce aprendizado do uso da indumentária masculina. "O vagaroso polimento das arestas efetua-se dia a dia nas reuniões sociais". (SOUZA, 1987, p. 166)

Na cidade de Nossa Senhora do Desterro, 
Sendo importante, rico ou de respeito, não prescindia do adôrno masculino por excelência. Glabro, cara raspada, só padre. Um ou outro que, para esnobar, barbeava-se à inglêsa, deixava suíças e costelas, pondo abaixo o restante. (CABRAL, 1979, p. 347)

Se a discreta pueril burguesia desterrense tinha seus lugares para deliciar-se diante das gentilezas e dos brilhos propiciados pelo consumo efêmero, os menos abastados encontravam nas esquinas, boticas e locandas o lugar da predileção dos seus sonhos, dos seus afetos, das suas necessidades, dos seus encontros casuais, das novidades produzidas pelas acelerações dos corações diante de um mundo onde os dizeres e fazeres, ao inocularem prescrições referentes ao viver, assinalavam o caminho a ser desvendado, experimentado e vivenciado.

No cotidiano da Ilha o gosto pelo uso dos chapéus, dos mais diversificados modelos, tamanhos e cores circulava nas festas religiosas. No ano de 1861, logo após participar dos festejos do Terno dos Reis, um anônimo, através das páginas do Jornal “O Argos", comunica à população a perda de "hum chapéo de sol de côr roxa, armação de latão e cabo de osso" (Jornal O Argos, 17-01- 1861). Obviamente, o distinto cavalheiro, gratificava quem o devolvesse.

Homens calvos, homens com cabelos soltos, com chapéus da moda, com bonés. Cavalheiros de bengalas de osso, bengalas de cabo encravado com diamantes e ouro. Gentleman de paletós de brim, de veludos, de calças de casimira francesa, de ceroulas, de gravatas. Homens de botas, de tamancos, de escarpins de verniz. Todos muito chics, gentis, distintos e prazerosos. Contudo, também havia os esquecidos, os distraídos que sempre levavam para casa algo que não lhes pertencia. E foi com o intuito de recuperar uma bengala de anéis de chifre que um cidadão através das páginas do Jornal "O Despertador" em 1873 solicita:

Roga-se à pessoa que, por engano, levou do baile que teve lugar na noite de 31 de maio p.p., na casa do $\mathrm{Ilm}^{\circ}$. Sr. Boaventura da Silva Vinhas, uma bengala de anéis de chifre, à imitação de coralina, com o castão imitando a mão de um cavalo, tendo na pata uma ferradura de prata, com as iniciais B. P. R., o favor de a entregar no hotel dos Paquetes, que será gratificada, se exigir. (Jornal O Despertador, 03-07-1873) 
Numa sociedade de ambiguidades como o demonstra a historiografia desterrense, "A festa era, para uma sociedade deste tipo, mais que para qualquer outra, a ruptura na rigidez dos costumes" e na medida em que o tempo foi passando e os ditames da arte do viver foram ditando prescrições nas relações cotidianas "repudiando intimidades excessivas, impondo regras estritas de decência", (SOUZA, 1987, p. 146). Dito de outra forma as representações, diante de um mundo que fenecia na fronteira tênue entre o profano e o sagrado, foram possibilitando espaço para transgressão.

Quando a existência se tornava cada vez mais árida, a vida quotidiana contrastava com a aspiração do sonho, e as energias feneciam [...], impondo-se a necessidade de uma evasão periódica, de uma pausa na ordem do mundo. A festa arremessava os seres nas remotas regiões da fantasia onde, livres temporariamente das interdições e da vigilância rigorosa, homens e mulheres se abandonavam ao ritmo de suas tendências. (SOUZA, 1987, p. 147)

Nesta perspectiva, poder-se-ia dizer que Nossa Senhora do Desterro, no transcurso do século XIX, constitui-se como objeto do cosmopolitismo e se "revela uma cidade civilizada voltada para o exterior, perseguindo um objetivo estético" que integrasse ao mesmo tempo aspectos referentes ao mundo urbano e ao comedimento dos gestos e atitudes." A moda descobrirá meios de, sem ofender a moral reinante, satisfazer um impulso reprimido", e ao mesmo tempo introduzir a estética como mediadora das efusões do efêmero. Fronteira tênue de simbologias que requeria um exercício constante dos códigos da arte do se fazer representar numa multiplicidade de etiquetas colocou no grupo masculino uma rigidez no vestuário " $A$ indumentária masculina evoluiu na sua trajetória de um "oblongo em pé”, sólido dos ombros aos tornozelos, ao segmento de uma estrutura assemelhando-se no desenho a um $\mathrm{H}^{\prime \prime}$ (SOUZA, 1987, p. 25-59-146).

Nas representações inoculadas pelas tipologias necessárias à difusão do homem moderno, o traje e suas significações compõem o universo dos dispositivos do que se pensa ser decente e rígido por princípios morais sólidos. 
A roupa masculina ainda é um instrumento de afirmação pessoal, e nas reuniões sociais o exagero é tão grande quanto o feminino, os desenhos do período explorando também os ridículos dos homens, como os bustos estufados artificialmente, os calções muito largos drapeados sobre as coxas, as gravatas monumentais que, juntamente com as golas altíssimas, engoliam rosto, cabeça e cartola. (SOUZA, 1987, p. 65)

A clivagem das condutas operacionalizadas na cidade ao difundir as prescrições dos comedimentos masculinos indicava, sutilmente:

Aparentemente as coisas não se passam mais da mesma maneira no século XIX: uma nova economia dos signos corporais estabelece-se progressivamente, modificando os gestos da emoção. Seguir a pista das lágrimas permite captar as modalidades desta transformação. (SOUZA, 1987, p. 11-12)

A grã-finagem da época também requeria dos cavalheiros o controle dos hábitos considerados inconvenientes. Os prazeres provocados pelo cintilar do efêmero deveriam referendar o glamour pelo exótico, mas a civilidade torna-se indispensável nas práticas afetivas da população da llha e de modo particular nas práticas de sociabilidade do indivíduo do sexo masculino.

A não ser que quisesse ser excluído do rol dos moços finos, candidatos a bons partidos matrimoniais, ser alijado da lista da gente "bem", jamais conseguindo noiva com quem pudesse casar, mesmo muito pobre tendo de contentar-se com qualquer amigação com u'a "moça", teúda e manteúda, e viver à margem da sociedade, sem um nome, sem um futuro....(SOUZA, 1987, p. 162)

Na sociedade desterrense, onde "o meio era pequeno e todos se conheciam" as relações de sociabilidade e de afetividade solicitavam um aprendizado constante diante dos ritos que percorriam faceiros pelas bucólicas esquinas da Ilha de Santa Catarina anunciando as novidades de uma vida milimetricamente contida. Afinal, "Era preciso ter uma conduta rígidamente prescrita - pois a não ser assim, não tinha vez o rapaz, muito 
menos a jovem que quisesse manter ou disputar um lugar na sociedade". (SOUZA, 1987, p. 47)

A preocupação com a aparência e de modo particular com o vestuário confere à moda um status inusitado pelo proselitismo que provoca diante das efusões dos sentidos.

Isto porque a vestimenta é uma linguagem simbólica, um estratagema de que o homem sempre se serviu para tornar inteligíveis uma série de idéias como o estado emocional, as ocasiões sociais, a ocupação ou o nível do portador. (SOUZA, 1987, p. 125)

Ao difundir a pedagogia do vestuário, os agentes da modernidade em Desterro indicavam estilos e cores. Criticava-se através dos jornais o mau gosto no vestir-se e os paletós "que destoavam em múltiplas cores" nos salões onde ocorriam as movimentadas soirés frequentadas pela fina flor da sociedade da Capital da Província de Santa Catarina.

Na noite de 7 do corrente teve lugar o concerto em beneficio do menino pianista Vasconcelos, o qual foi duplamente aplaudido pelo grande numero de cavalheiros e damas que concorrerão á esse concerto. Consta-nos que muitos dos ilustres cavalheiros presentes vestiam-se num mau gôsto que feria o olhar sensível. Alguns usavam paletó que destoavam em múltiplas cores. Nada mais adiantamos porque não fizemos parte de tão ilustre reunião. (Jornal O Comercial, 08-01-1868)

A roupa e os modos de se vestir se colocavam para a principesca sociedade desterrense como o novo sistema de distinção às inevitáveis comparações de bom gosto e requinte. Nas entrelinhas dos discursos, sutilmente, estimulava-se a necessidade de que “os indivíduos devem realizar sua revolução pessoal”. As aparências deveriam refletir o prazer de adivinhar e permitir através do vestuário que "a invasão dos novos símbolos públicos nos espaços privados" fossem determinantes para a criação e o entendimento das novas configurações de sociabilidade e afetividade enquanto a roupa masculina traduzia sobriedade e seriedade. 
A moda masculina não se definiu de imediato com tanta clareza, mas a indumentária logo se transformou num sistema semiótico intensamente carregado. Ela revela o significado público do homem privado. [...]. A partir de 1792, o barrete vermelho, o casaco estreito com várias filas de botões e as calças largas passam a definir o sans-culotte. (HUNT, 1991, p.24)

Neste período, em Nossa Senhora do Desterro, estimulava-se a preocupação com o vestir. O homem probo em sintonia com a modernidade, com a prosperidade, com a educação e comprometido com o progresso valorizava as aparências. O traje e a indumentária eram interpretados como instrumento da elegância e do recato. Estar bem vestido, na moda, ajudava na difusão da cordialidade, da economia, da cultura, da política e da família. "Considerava-se grosseiro o homem não usar a sobrecasaca ou um casaco para a manhã na cidade, ao fazer visitas ou ao tomar parte no serviço religioso dominical” (LAVER, 1989, p. 206).

Assim, Nossa Senhora do Desterro, no seu principesco cosmopolitismo, que procura pautar sua vida pelo ritmo da moda, via-se inserida nos vários dizeres sobre a civilidade. Elemento de prestígio, o vestuário e o comedimento das atitudes conferiam ao homem distinção e probidade, nessa época quando as representações indicavam que o caminho a ser conquistado passava por um certo dispêndio do tempo. A lapidação da imagem pessoal inseria-se na ambiguidade produzida pelas clivagens das condutas diante do hábito de cultivar e registrar, pelas aparências, uma marca individual.

Na medida em que a cidade de Nossa Senhora do Desterro inseria-se no processo cosmopolita e difundia a pedagogia das clivagens das condutas, os periódicos constituíam-se em dispositivos que corrigiam e regulamentavam as atitudes consideradas desnecessárias e importunas diante dos novos códigos de sociabilidade. Nas suas páginas perfilam o esmero, a civilidade, as modas, a prosperidade, a clivagem das condutas, a virtude, a família e a urbanidade com seus equipamentos de sociabilidade. Em seus editoriais, crônicas, notas, advertências e publicações a pedido o compósito dos dizeres e dos fazeres tinham como preponderância a argumentação crítica aos costumes considerados antiquados que corroíam e arruinavam a capacidade de progresso. 
Para os ávidos de modernidade, urbanidade e prosperidade a Capital da Província de Santa Catarina necessitava adequar-se ao cosmopolitismo concomitante a mudanças internas. As prescrições sobre o uso das modas e dos modos qualificavam o sujeito e o instrumentalizava perante os códigos de civilidade. "Exemplo disto, entre outros, é a verdadeira mania ambulatória que irrompe então por toda parte e que o desenvolvimento" (Souza, 1987, p. 156) das etiquetas que proliferavam no cotidiano desterrense possibilitavam ao sujeito o seu próprio ordenamento cosmopolita. Neste sentido o vestuário e o efêmero da moda possibilitava o imensurável diante das prescrições sobre a moda e seus efeitos sobre a arte do comedimento das atitudes e dos gestos socializantes.

Nesta perspectiva a urbanidade, a afetividade e a sociabilidade solicitavam ao comportamento masculino um trasbordamento intermitente de polidez e generosidade. Com isto, fazia-se a junção do mundo público e privado. Nas suas fronteiras, de modo imperceptível, a representação de sociabilidade emergia pela superfície da Ilha de Santa Catarina. "Nessa sociedade hierarquicamente estruturada, todos os atos praticados na presença de numerosas pessoas adquiriam valor e prestígio. Por este motivo, o controle das emoções, aquilo que chamamos de "polidez" (ELIAS, 1994, p. 144).

O aproximar desses dois polos e a sua consolidação diante dos dizeres sobre a intimidade dos sujeitos e sua vida pública requeriam metáforas que se constituíam em pantomimas reconfortantes diante de um mundo de representações e simulações. "O poder de simulação, colocado em primeiro plano pela contestação das aparências, redistribui a apreensão dos signos da emoção". (VICENT-BUFFAULT, 1988, p. 192)

Próspera, polida e higienizada, Nossa Senhora do Desterro, ecoava pelos seus recônditos os seus mais íntimos e intensos aprendizados. E na medida em que certa prosperidade e urbanidade, tímida, porém incisiva, circula com desenvoltura sobre a superfície da póvoa, da vila e da cidade de Nossa Senhora do Desterro

A necessidade do supérfluo se impõe pelo pretexto de uma nova relação com o mundo e as coisas que garantem, embelezam e tranqüilizam. A virtude não é mais o fruto da renúncia e sim a utilização moderada e 
racional dos bens e dos benefícios que eles prodigalizam. (ROCHE, 2000, p. 108)

Assim, Nossa Senhora do Desterro, no seu principesco cosmopolitismo, que procura pautar sua vida pelo ritmo da moda, via-se inserida nos vários dizeres sobre a civilidade. Elemento de prestígio, o vestuário e o comedimento das atitudes conferiam ao homem distinção e probidade, nessa época quando as representações indicavam que o caminho a ser conquistado passava por certo dispêndio do tempo. A lapidação da imagem pessoal inseria-se na ambiguidade produzida pelas clivagens das condutas diante do hábito de cultivar e registrar, pelas aparências, uma marca individual.

Estas breves relações superficiais quase sempre sem conseqüências, que se estabelecem entre indivíduos. [...]. É a lembrança constante do artifício que nos embaraça e nos perturba, e o nosso enleamento, contrastado com a desenvoltura dos outros, patenteia, aos olhos de todos, aqueles afastamentos que o disfarce das roupas não conseguiu apagar. (SOUZA, 1987, p. 116-169)

\section{Referências Bibliográficas}

BERGER, Paulo (Org.). Ilha de Santa Catarina: relatos de viajantes estrangeiros nos séculos XVIII e XIX. 2. ed .Florianópolis : UFSC/Assembléia Legislativa, 1984.

BOLOGNE, Jean Claude. História do Pudor. Trad. de Tela Costa. Rio de Janeiro: Elfos Ed; Lisboa : Teorema, 1990.

CABRAL, Oswaldo Rodrigues. Nossa Senhora do Desterro. Florianópolis : Lunardelli, 1979. V. 1.

CORBIN, Alain. O Segredo do Indivíduo. In: PERROT, Michelle et al., (Org.). História da Vida Privada: Da revolução Francesa à Primeira Guerra. São Paulo: Companhia das Letras, 1991.

Correio Catharinense.Florianópolis, 22 dez. 1852.

DOM PERNETTY, Antonie. Histoire d' um Voyage aux Isles Malouines, fait em 1763-1764. Paris, chez Saillant Nyon, Delalain, 1770. In: Berger, Paulo (Org.). Ilha de Santa Catarina: 
relatos de viajantes estrangeiros nos séculos XVIII e XIX. 2. ed. Florianópolis: Editora da UFSC/Assembléia Legislativa, 1984.

DUPERREY, Louis Isidore. Voyage autour du Monde [...]. Paris : Artus Bertrand. LibraireÉditeur. 1829. Trad. de Gilberto Gerlach e Martins Afonso Palma de Haro. In: Berger, Paulo (Org.). Ilha de Santa Catarina: relatos de viajantes estrangeiros nos séculos XVIII e XIX. 2. ed. Florianópolis: Editora da UFSC/Assembléia Legislativa, 1984.

ELIAS, Nobert. O processo civilizador. Rio de Janeiro: Jorge Zahar Ed., 1994. V. II

HUNT, Lynn. Revolução francesa e a vida Privada. In: PERROT, Michelle et al. (Org.). História da vida privada: Da revolução Francesa à Primeira Guerra. São Paulo : Companhia das Letras, 1991.

LANGSDORFF, G.H. von. Bemerkungen auf einer Reise um die Welt in dean Jahren 1805 bis 1807. Trad. de Dolores R. Simôes de Almeida. In: Berger, Paulo (Org.). Ilha de Santa Catarina: relatos de viajantes estrangeiros nos séculos XVIII e XIX. 2. ed. Florianópolis: Editora da UFSC/Assembléia Legislativa, 1984.

LAVER, James. A Roupa e a Moda: uma história concisa. Trad. Glória Maria de Mello Carvalho. São Paulo: Companhia das Letras, 1989.

LIPOVETSKY, Gilles. O Império do efêmero: a moda e seu destino nas sociedades modernas.. São Paulo: Companhia das Letras, 1989.

O Argos. Florianópolis, 22 maio 1852.

O Argos. Florianópolis, 17 jan. 1861.

O Comercial. Florianópolis, 08 jan. 1868.

O Despertador. Florianópolis, 29jun. 1869.

O Despertador. Florianópolis, 22 jan. 1870.

O Despertador. Florianópolis, 03 jul. 1873.

PORTER, David. Giornale di uma Crociera fatta nell' Oceano Pacífico. Milano. Dalla tipografia di Giambattista Sonzogno. 1820. Trad. de Inácio Dell'Antônio. In: Berger, Paulo (Org.). Ilha de Santa Catarina: relatos de viajantes estrangeiros nos séculos XVIII e XIX. 2. ed., Florianópolis: Editora da UFSC/Assembléia Legislativa, 1984. 
ROCHE, Daniel. História das coisas banais: nascimento do consumo nas sociedades do século XVII ao XIX. Rio de janeiro: Rocco, 2000.

SAINT-HILAIE, Auguste de. Viagem a Curitiba e Santa Catarina. Belo Horizonte: Itatiaia: Ed. da Universidade de São Paulo, 1978.

SOUZA, Gilda de Mello e. O espírito das roupas: a moda no século dezenove. São Paulo: Companhia das Letras, 1987.

VICENT-BUFFAUT, Anne. História das Lágrimas: séculos XVIII e XIX. Rio de Janeiro: Paz e Terra, 1988. 